\title{
Significance of Cardiac Involvement in Fabry Disease
}

\author{
Dae Wook Lee* \\ Takeda Pharmaceutical Ltd, Asia-Pacific Region, Singapore
}

Submission: November 26, 2019; Published: December 04, 2019

*Corresponding author: Dae Wook Lee, Takeda Pharmaceutical Ltd, Medical Affairs, Asia-Pacific Region, Singapore

Keywords: Fabry disease; X chromosome; Altered metabolism; Glycosphingolipid; Lysosomes; Dermatological blood vessel

\section{Mini Review}

Fabry Disease (FD) is a rare form of progressive genetic disorder, which results on damages to multi-organs especially cardio-renal system [1]. As for the genetic origin, FD is occurred due to the specific mutation of the GLA gene, which is routed on $\mathrm{X}$ Chromosome, where currently more than 800 types of different GLA mutations have been reported [1,2].

The accurate incidence and prevalence of Fabry disease has ranged between different populations from 1:336,000 in males (11) and 1:339,000 in female carriers in U.K. (12), and more common to $1: 1,250$ in males and 1:40,840 in females in Taiwan accordingly (13). As the true prevalent rates in females are still unknown, however due to the involvement of X-linked inheritance the female prevalence estimated at approximately 1:20,000 (14), which is twice folds to male incident rate on Fabry disease was expected in 1:40,000 in reported study (15).

Based on the genetic mutated forms, even a single-point mutation for GLA gene is pathogenic to develop the manifestation of Fabry Disease [3]. GLA mutation consequence the altered metabolism of specific glycosphingolipid known as Gb3, this will also cascade to glycolipid $\mathrm{Gb} 3$ accumulation in lysosomes of various cell types in organ systems including cardiac, renal, ophthalmology or nervous system, and dermatological blood vessel lining cells in complication [4-9], causing lysosomal $\alpha$-Gal A enzyme deficiency in net effects of increase level of plasma degrading substance of lyso-GB3 [1,5,6,10-14].

Due to the complex relationship with their association with genotype and morphological features, the classical clinical presentation of Fabry disease varies within patients population with even identical gene mutation, which makes a simultaneous heterogeneity on multi-organ facets on clinical symptoms
$[1,15,16]$, where residual $\alpha$-Gal A enzyme activity tend to resemble fewer symptomatic progressions as a slow progressive pathology $[16,17]$.

One of the most commonly involvement vital organ as cardiac components is known to be the major source of the Fabry disease mortality and their co-morbidities [18]. Cardiac involvement of Fabry Disease is typically manifested by inflammatory nature of the late-stage complication of the organ damage, which lead by pathogenic oxidative stress, endothelial dysfunction, and multisystematic inflammatory vasculopathy mimicking the tissue remodeling as fibrosis and sclerosis of cardiac tissue [19-22].

With debilitating inflammatory changes in cardiac tissue results predominantly in left ventricle of the cardiac chambers, which leads to increased oxidative stress could manifest hypertrophic cardiomyopathies from left ventricular dysfunction, left ventricular hypertrophy, and abnormalities of signal conduction system, and adjacent valve dysfunctions [22-26]. The cardiac manifestation is also accounted for almost $60 \%$ of all mortalities in Fabry disease population [27,23], whereas cerebrovascular complications such as stroke and TIA are also accounted in $21 \%$ and $25 \%$ of female/male FD in ratio [28].

The diagnosis of cardiac complications is assessed by cardiography methodology including ECG, Echocardiography, cardiac function test, and 24-hours Holter for accurate determination of disease extents [29]. With either symptoms indicative of FD or family member with known Fabry disease patients are also referred to biochemical and genetic tests, which segmented to males for measurement of plasma $\alpha$-Gal A activity with urinary/plasma Gb3 or degradation product lyso-Gb3, accompanying with confirmatory GLA gene mutation by genetic 
analysis [29]. In females, due to the X-linked chromosome, genetic analysis and testing on GLA gene is essential methods to diagnose Fabry disease [29].

The important aspects on diagnosis of Fabry disease is based on the duration undertaken in prior to confirmatory findings on the genetic assessment which commonly lead to delays by the characteristic on symptomatic non-specificity and diverse presentation with less acknowledgement on disease state $[27,29]$. The average delay expected from first symptom presentation to diagnosis was reported in ranges from 12 years to 16 years, and even exceeding a long-term diagnostic delay more than 20 years were frequently seen with sequential consultations from multispecialists including potential risks of differential or misdiagnosis $[27,30]$. In contrary to diagnostic delay, the quality of life in Fabry disease when early in life is significantly compromised with deteriorating consequences [31].

The treatment of Fabry disease requires a multi-displinary approach, which most essential treatment is the management of underlying enzyme deficiency by Enzyme Replace Therapy (ERT) such as Agalsidase alfa to slow the progression of the disease by their mechanism of action in supplement of exogenous enzyme intravenously to target lysosome via receptor-mediated endocytosis at cellular level with net effects of reduction of substrate amounts leading to inhibit glycosphingolipid synthesis $[32,33]$. ERT is also indicated as a long-term correction of enzyme deficiency of Fabry Disease with tolerance [33].

In combination to ERT, supportive treatment for specific cardiac symptoms are also adjuvant with Fabry disease, which the common treatments of ACE inhibitors, ARBs, anti-arrhythmics, diuretics, and Pacemaker at late cardiac complication are considered [34,35]. Thus, the principle of comprehensive management would be key to prevent the further organ damage and disease progression of Fabry disease, early involvements of multi-displinary contribution would enhance the patient's longterm modalities and their further improvement in quality of life within rare condition on Fabry disease [1,34,35-39].

\section{References}

1. Schäfer E, Baron K, Widmer U, Deegan P, Neumann HPH, et al. (2005) Thirty-four novel mutations of the GLA gene in 121 patients with Fabry disease. Hum Mutat 25(4): 412.

2. Benjamin ER, Della Valle MC, Wu X, Katz E, Pruthi F, et al. (2017) The validation of pharmacogenetics for the identification of Fabry patients to be treated with migalastat. Genet Med 19(4): 430-438.

3. Garman SC, Garboczi DN (2004) The molecular defect leading to Fabry disease: structure of human alpha-galactosidase. J Mol Biol 337(2): 319-335.

4. Desnick RJ, Blieden LC, Sharp HL, Hofschire PJ, Moller JH (1976) Cardiac valvular anomalies in Fabry disease. Clinical, morphologic, and biochemical studies. Circulation 54(5): 818-825.

5. Schibanoff JM, Kamoshita S, O'Brien JS (1969) Tissue distribution of glycosphingolipids in a case of Fabry's disease. J Lipid Res 10(5): 515520.
6. Desnick RJ (2001) In: Scriver R, et al. (eds.), The Metabolic and Molecular Bases of Inherited Disease. New York: McGraw-Hill, New York 3733-3774.

7. Garman SC, Garboczi DN (2004) The molecular defect leading to Fabry disease: structure of human alpha-galactosidase. J Mol Biol 337(2): 319-335.

8. Testai FD, Gorelick PB (2010) Inherited metabolic disorders and stroke part 1: Fabry disease and mitochondrial myopathy, encephalopathy, lactic acidosis, and strokelike episodes. Arch Neurol 67(1): 19-24.

9. Hoffmann B (2009) Fabry disease: recent advances in pathology, diagnosis, treatment and monitoring. Orphanet J Rare Dis 4: 21-29.

10. Brady RO, Gal AE, Bradley RM, Martensson E, Warshaw AL, et al. (1967) Enzymatic defect in Fabry's disease. Ceramidetrihexosidase deficiency. N Engl J Med 276(21): 1163-1167.

11. Lemansky P, Bishop DF, Desnick RJ, Hasilik A, von Figura K (1987) Synthesis and processing of alpha-galactosidase $\mathrm{A}$ in human fibroblasts. Evidence for different mutations in Fabry disease. J Biol Chem 262(5): 2062-2065.

12. Mehta A (2002) Agalsidase alfa: specific treatment for Fabry disease. Hosp Med 63(6): 347-350.

13. Niemann M, Rolfs A, Störk S, Bijnens B, Breunig F, et al. (2014) Gene mutations versus clinically relevant phenotypes: lyso-Gb3 defines Fabry disease. Circ Cardiovasc Genet 7(1): 8-16.

14. Rombach SM, Smid BE, Linthorst GE, Dijkgraaf MGW, Hollak CEM (2014) Natural course of Fabry disease and the effectiveness of enzyme replacement therapy: a systematic review and meta-analysis: effectiveness of ERT in different disease stages. J Inherit Metab Dis 37(3): 341-352.

15. Ries M, Gal A (2006) In: Mehta A et al., editors. Fabry disease: perspectives from 5 years of FOS. Oxford: Oxford PharmaGenesis.

16. De Brabander I, Yperzeele L, Ceuterick-De Groote C, Brouns R, Baker R, et al. (2013) Phenotypical characterization of $\alpha$-galactosidase A gene mutations identified in a large Fabry disease screening program in stroke in the young. Clin Neurol Neurosurg 115(7): 1088-1093.

17. Desnick RJ (2001) In: Scriver R et al, editors. The Metabolic and Molecular Bases of Inherited Disease. New York: McGraw-Hill 37333734.

18. Morier AM, Minteer J, Tyszko R, McCann R, Virginia Clarke M, et al. (2010) Ocular manifestations of Fabry disease within in a single kindred. Optometry 81(9): 437-449.

19. Biancini GB, Moura DJ, Manini PR, Faverzani JL, Oliveira Netto CB, et al. (2015) DNA damage in Fabry patients: An investigation of oxidative damage and repair. Mutat Res Genet Toxicol Environ Mutagen 784785: 31-36.

20. Namdar M, Gebhard C, Studiger R, Shi Yi, Mocharla P, et al. (2012) Globotriaosylsphingosine accumulation and not alpha-galactosidase-A deficiency causes endothelial dysfunction in Fabry disease. PLoS One 7(4): e36373.

21. Mauhin W, Lidove O, Masat E, Mingozzi F, Mariampillai K, et al. (2015) Innate and Adaptive Immune Response in Fabry Disease. JIMD Rep 22: $1-10$.

22. Chimenti C, Scopelliti F, Vulpis E, Tafani M, Villanova L, et al. (2015) Increased oxidative stress contributes to cardiomyocyte dysfunction and death in patients with Fabry disease cardiomyopathy. Hum Pathol 46(11): 1760-1768.

23. Morrissey RP, Philip KJ, Schwarz ER (2011) Cardiac abnormalities in Anderson-Fabry disease and Fabry's cardiomyopathy. Cardiovasc J Afr 22(1): 38-44. 
24. Elliott PM, Kindler H, Shah JS, Sachdev B, Rimoldi OE, et al. (2006) Coronary microvascular dysfunction in male patients with AndersonFabry disease and the effect of treatment with alpha galactosidase A. Heart 92(3): 357-360.

25. Kampmann C, Baehner F, Whybra C, Martin C, Wiethoff CM, et al. (2002) Cardiac manifestations of Anderson-Fabry disease in heterozygous females. J Am Coll Cardiol 40(9): 1668-1674.

26. Shah JS, Elliott PM (2005) Fabry disease and the heart: an overview of the natural history and the effect of enzyme replacement therapy. Acta Paediatr Suppl 94(447): 11-14.

27. Mehta A, Ricci R, Widmer U, Dehout F, de Lorenzo AG, et al. (2004) Fabry disease defined: baseline clinical manifestations of 366 patients in the Fabry Outcome Survey. Eur J Clin Invest 34(3): 236-242.

28. Mehta A, Clarke JT, Giugliani R, Elliott P, Linhart A, et al. (2009) Natural course of Fabry disease: changing pattern of causes of death in FOS Fabry Outcome Survey. J Med Genet 46(8): 548-552.

29. Mehta A, Beck M, Eyskens F, Feliciani C, Kantola I, et al. (2010) Fabry disease: a review of current management strategies. QJM 103(9): 641659.

30. Mehta A, Beck M, Sunder-Plassmann G (2006) In: Mehta et al., editors. Fabry disease: perspectives from 5 years of FOS. Oxford: Oxford PharmaGenesis.

31. Hoffmann B, Beck M, Sunder-Plassmann G, Borsini W, Ricci R, et al. (2007) Nature and prevalence of pain in Fabry disease and its response to enzyme replacement therapy--a retrospective analysis from the Fabry Outcome Survey. Clin J Pain 23(6): 535-542.
32. Hollak CE, Vedder AC, Linthorst GE, Aerts JM (2007) Novel therapeutic targets for the treatment of Fabry disease. Expert Opin Ther Targets 11(6): 821-833.

33. Replagal®. Summary of Product Characteristics. Shire Human Genetic Therapies.

34. Hughes, et al. (2005) Guidelines for the diagnosis and management of Anderson-Fabry disease Department of Health.

35. Hughes D, et al. (2013) UK Adult Fabry Disease Standard Operating Procedures.

36. MacDermot KD, Holmes A, Miners AH (2001) Anderson-Fabry disease: clinical manifestations and impact of disease in a cohort of 98 hemizygous males. J Med Genet 38(11): 750-760.

37. MacDermot KD, Holmes A, Miners AH (2001) Anderson-Fabry disease: clinical manifestations and impact of disease in a cohort of 60 obligate carrier females. J Med Genet 38(11): 769-775.

38. Hwu WL, Chien YH, Lee NC, Chiang SC, Dobrovolny R, et al. (2009) Newborn screening for Fabry disease in Taiwan reveals a high incidence of the later-onset GLA mutation c.936+919G>A (IVS4+919G>A). Hum Mutat 30(10): 1397-1405.

39. Laney DA, Fernhoff PM (2008) Diagnosis of Fabry disease via analysis of family history. J Genet Couns 17(1): 79-83.

\section{Your next submission with Juniper Publishers will reach you the below assets}

- Quality Editorial service

- Swift Peer Review

- Reprints availability

- E-prints Service

- Manuscript Podcast for convenient understanding

- Global attainment for your research

- Manuscript accessibility in different formats

( Pdf, E-pub, Full Text, Audio)

- Unceasing customer service

Track the below URL for one-step submission https://juniperpublishers.com/online-submission.php 